\title{
Pengaruh Pemupukan Nitrogen terhadap Produksi Rumput Sorghum nitidum pada Umur Panen yang Berbeda
}

\author{
Effect of Nitrogen Fertilization on Production of Sorghum nitidum Grass at Different \\ Harvesting Time
}

\author{
F. K. Keraf dan E. Mulyanti \\ Balai Besar Pelatihan Peternakan Kupang \\ keraffabianus@gmail.com
}

\begin{abstract}
This research aimed in evaluating the effect of nitrogen fertilizer and different harvesting time on the production and quality of sorghum grass nitidum. This research was fully conducted in a greenhouse at the Center for Training Ranch Kupang. The design used was completely randomized design (CRD) factorial with four levels of nitrogen fertilizer (factor 1) and 6 levels of harvesting time (factor 2) with four times replication. The parameters measured were the growth rate, the number of seedlings and the produced plant biomass. The collected data were analyzed by using analysis of variance and the results indicated that nitrogen fertilizer had a very significant effect on several measured parameters including the rate of growth $(\mathrm{P}<0.01)$, the number of tillers and the production of crude protein. It was also found that the nitrogen fertilizer significantly affected the dry matter production, the production of organic materials and coarse fibers $(\mathrm{P}<0.05)$. Different harvesting time was found to have highly significant effect $(\mathrm{P}<0.01)$ on all the observed parameters. Finally, the interaction between both factors was found to have no effect $(\mathrm{P}>0.05)$ on the rate of growth, the production of dry matter, organic matter, crude protein and crude fiber and significant effect on $(\mathrm{P}<0.5)$ to the number of tillers.
\end{abstract}

Key words: nitidum grass, nitrogen fertilizer, harvesting time

\begin{abstract}
ABSTRAK
Penelitian dengan tujuan mengetahui produksi dan kualitas rumput sorghum nitidum akibat pemupukan nitrogen dan umur panen yang berbeda, telah dilakukan di green house milik Balai Besar Pelatihan Peternakan Kupang. Rancangan yang digunakan adalah Rancangan Acak Lengkap (RAL) pola faktorial dengan 4 level pupuk nitrogen (faktor 1) dan 6 level umur panen (faktor 2) yang diulang 4 kali. Parameter yang diamati adalah laju pertumbuhan, jumlah anakan dan produksi biomasa tanaman. Data yang diperoleh dianalisis menggunakan analisis variansi dimana hasil penelitian menunjukkan bahwa pupuk nitrogen berpengaruh sangat nyata $(\mathrm{P}<0,01)$ terhadap laju pertumbuhan, jumlah anakan dan produksi protein kasar namun berpengaruh nyata $(\mathrm{P}<0,05)$ terhadap produksi bahan kering, bahan organik dan serat kasar. Faktor umur panen berpengaruh sangat nyata $(\mathrm{P}<0,01)$ terhadap semua parameter yang diamati. Interaksi kedua faktor tidak berpengaruh $(\mathrm{P}>0,05)$ terhadap laju pertumbuhan, produksi bahan kering, bahan organik, protein kasar dan serat kasar, namun berpengaruh nyata $(\mathrm{P}<0,5)$ terhadap jumlah anakan.
\end{abstract}

Kata kunci : Rumput Sorghum nitidum, pupuk nitrogen, umur panen.

\section{PENDAHULUAN}

Salah satu jenis rumput lokal yang merupakan hijauan alternatif masyarakat di daerah sumba adalah rumput Sorghum nitidum, dimana rumput ini dapat beradaptasi dengan baik pada kondisi lingkungan. Rumput tersebut pertumbuhannya cepat seirama dengan berlangsungnya musim hujan. Kebanyakan peternak di NTT mengandalkan rumput introduksi lainnya untuk dijadikan sebagai pakan ternak, seperti rumput gajah, rumput raja, rumput benggala dan sebagainya sehingga rumput moru kapuka tumbuh secara liar tanpa melakukan teknik 
budidaya seperti halnya rumput introduksi lainnya. Potensi produksi rumput $S$. nitidum ini cukup tinggi sebagai pakan lokal, dan hijauan ini dapat bernilai ekonomis karena memiliki karakteristik pertumbuhan yang berbeda dengan rumput introduksi lainnya dimana tanaman ini pekah dan resisten terhadap iklim serta kondisi tanah di daerah pulau sumba karena dapat menampakan warna hijau pada musim kemarau yang panjang.

Dalam menerapkan teknik budidaya rumput $S$. nitidum perlu diperhatikan jumlah kebutuhan pupuk nitrogen agar rumput dapat berproduksi secara optimum. Hal tersebut merupakan sesuatu yang sangat menarik dan berharga, sehingga penulis merasa perlu untuk melakukan pengkajian untuk mendapatkan informasi yang bermanfaat dalam upaya membudidayakan rumput $S$. nitidum sebagai pakan lokal yang potensial untuk ternak ruminansia.

\section{MATERI DAN METODE}

Penelitian dilaksanakan di lahan praktek tanaman pakan ternak milik Balai Besar Pelatihan Peternakan Kupang, yang terletak di Jl. Timor Raya, desa Noelbaki, kecamatan Kupang Tengah, Kabupaten Kupang, Nusa Tenggara Timur selama kurang lebih 6 bulan. Materi yang digunakan dalam penelitian ini adalah anakan rumput $S$. nitidum umur tumbuh 1 minggu yang diambil dari kepulauan sumba, polybag berukuran $25 \times 18 \mathrm{~cm}$ dan pupuk urea sebagai sumber $\mathrm{N}(45 \%)$.
Selanjutnya dilakukan persiapan berupa pengisian tanah pada polybag dan ditanami anakan rumput $S$. nitidum sebanyak 2 anakan. Penyiraman dilakukan setiap hari dan pada minggu ke dua setelah penanaman dilakukan pemupukan nitrogen dengan dosis sesuai perlakuan. Pemanenan dilakukan dengan memotong setiap tanaman setinggi $10 \mathrm{~cm}$ dari permukaan tanah setiap 2 minggu sesuai perlakuan, yang diawali dengan menghitung jumlah anakan yang tumbuh serta mengukur tinggi tanaman dan dilanjutkan dengan pengukuran produksi segar serta melakukan reparasi sampel untuk dilakukan analisis proksimat di Balai Penelitian Ternak Ciawi.

Penelitian ini menggunakan Rancangan Faktorial dengan 2 faktor perlakuan dan masing-masing diulang 4 kali, yaitu faktor pertama adalah level pupuk nitrogen $(\mathrm{N})$ yang terdiri dari: $\mathrm{N}_{0}$ : tanpa pupuk (kontrol), $\mathrm{N}_{5}: 50 \mathrm{~kg} / \mathrm{Ha}$, $\mathrm{N}_{10}: 100 \mathrm{~kg} / \mathrm{Ha}$ dan $\mathrm{N}_{15}: 150 \mathrm{~kg} / \mathrm{Ha}$. Faktor kedua adalah umur tanaman (M) yang terdiri dari $\mathrm{M}_{2}$ : umur 2 minggu, $\mathrm{M}_{4}$ : umur 4 minggu, $M_{6}$ : umur 6 minggu, $M_{8}$ : umur 8 minggu, $\mathrm{M}_{10}$ : umur 10 minggu dan $\mathrm{M}_{12}$ : umur 12 minggu. Hasil analisis akan diuji lanjut dengan Uji Jarak Berganda Duncan menurut Steel dan Torrie (1993).

\section{HASIL DAN PEMBAHASAN}

\section{Laju Pertumbuhan dan Jumlah Anakan}

Pertumbuhan tanaman berupa perpanjangan dan pembesaran sel merupakan salah satu ciri yang nampak dalam dunia pertanian berupa perubahan tinggi dan 
penambahan generasi vegetatif baru.

Kemampuan untuk bereproduksi secara vegetatif biasanya terdapat pada tumbuhan herba termasuk tanaman S. nitidum. Analisis varians menggambarkan bahwa pupuk nitrogen dan umur tanaman berpengaruh sangat nyata $(\mathrm{P}<0,01)$ terhadap laju tumbuh dan jumlah anakan, sedangkan interaksi kedua faktor tersebut tidak berpengaruh ( $\mathrm{P}>0,05)$ terhadap laju pertumbuhan dan berpengaruh nyata $(\mathrm{P}<0,05)$ terhadap jumlah anakan rumput $S$. nitidum. Data Laju pertumbuhan dan jumlah anakan rumput $S$. nitidum dapat dilihat pada tabel 1 berikut ini:

Tabel 1. Laju pertumbuhan dan jumlah anakan rumput Sorghum nitidum akibat perlakuan

\begin{tabular}{|c|c|c|c|c|}
\hline $\begin{array}{l}\text { Dosis Pupuk } \\
\text { Tanaman }\end{array}$ & Umur & $\begin{array}{l}\text { Tinggi } \\
\text { Tanaman } \\
(\mathrm{cm})\end{array}$ & $\begin{array}{l}\text { Laju } \\
\text { Pertumbuhan } \\
\text { (cm/hari) }\end{array}$ & $\begin{array}{l}\text { Jumlah anakan } \\
\text { (polls) }\end{array}$ \\
\hline \multirow{6}{*}{$\begin{array}{c}\text { Tanpa Pupuk } \\
\text { Nitrogen } \\
\left(\mathrm{N}_{0}\right)\end{array}$} & 2 Minggu & 45,25 & $0,55 \pm 0,33^{\mathrm{a}}$ & $2 \pm 1,63^{\mathrm{a}}$ \\
\hline & 4 Minggu & 76,75 & $1,57 \pm 0,44^{\mathrm{efgh}}$ & $6 \pm 1,26^{\mathrm{a}}$ \\
\hline & 6 Minggu & 67,50 & $0,64 \pm 0,28^{\mathrm{ab}}$ & $18 \pm 16,36^{\mathrm{abc}}$ \\
\hline & 8 Minggu & 98,75 & $1,08 \pm 0,07^{\text {abcdefg }}$ & $21 \pm 5,60^{\mathrm{abcd}}$ \\
\hline & 10 Minggu & 87,75 & $0,73 \pm 0,20 \mathrm{abc}$ & $59 \pm 27,66^{\text {ef }}$ \\
\hline & 12 Minggu & 99,25 & $0,79 \pm 0,06^{\mathrm{abcd}}$ & $28 \pm 14,38^{\mathrm{abcd}}$ \\
\hline \multirow{6}{*}{$\begin{array}{c}\text { Dosis Pupuk } \\
\text { Nitrogen } \\
50 \mathrm{~kg} / \mathrm{ha}\end{array}$} & 2 Minggu & 54,25 & $1,14 \pm 0,79^{\text {abcdefg }}$ & $3 \pm 1,4^{\mathrm{a}}$ \\
\hline & 4 Minggu & 71,75 & $1,36 \pm 0,50^{\text {cdefgh }}$ & $6 \pm 1,83^{a}$ \\
\hline & 6 Minggu & 71,00 & $0,96 \pm 0,19^{\text {abcdef }}$ & $35 \pm 25,88^{\text {bcde }}$ \\
\hline & 8 Minggu & 102,5 & $1,26 \pm 0,22^{\text {bcdefg }}$ & $45 \pm 23,01^{\text {cde }}$ \\
\hline & 10 Minggu & 113,75 & $1,10 \pm 0,19^{\text {abcdefg }}$ & $72 \pm 20,90^{\mathrm{fg}}$ \\
\hline & 12 Minggu & 126,25 & $1,00 \pm 0,18^{\text {abcdefg }}$ & $35 \pm 21,74^{\text {bcde }}$ \\
\hline \multirow{6}{*}{$\begin{array}{c}\text { Dosis Pupuk } \\
\text { Nitrogen } \\
100 \mathrm{~kg} / \mathrm{ha}\end{array}$} & 2 Minggu & 57,50 & $1,46 \pm 0,71^{\text {defgh }}$ & $5 \pm 2,99^{a}$ \\
\hline & 4 Minggu & 71,38 & $1,63 \pm 0,50^{\text {fgh }}$ & $7 \pm 4,78^{a}$ \\
\hline & 6 Minggu & 93,25 & $1,28 \pm 0,38^{\text {bcdefg }}$ & $25 \pm 12,52^{\mathrm{abcd}}$ \\
\hline & 8 Minggu & 112,75 & $1,35 \pm 0,40^{\text {cdefgh }}$ & $29 \pm 20,50^{\text {abcd }}$ \\
\hline & 10 Minggu & 101,25 & $0,98 \pm 0,25^{\text {abcdefg }}$ & $96 \pm 38,85^{\text {ef }}$ \\
\hline & 12 Minggu & 114,25 & $0,93 \pm 0,20^{\text {abcde }}$ & $59 \pm 24,59^{\text {gh }}$ \\
\hline \multirow{6}{*}{$\begin{array}{l}\text { Dosis Pupuk } \\
\text { Nitrogen } \\
150 \mathrm{~kg} / \mathrm{ha}\end{array}$} & 2 Minggu & 68,50 & $2,50 \pm 0,99^{i}$ & $5 \pm 1,73^{\mathrm{a}}$ \\
\hline & 4 Minggu & 88,50 & $1,96 \pm 0,40^{\text {hi }}$ & $11 \pm 3,92^{\mathrm{ab}}$ \\
\hline & 6 Minggu & 99,75 & $1,48 \pm 0,34^{\mathrm{efgh}}$ & $47 \pm 16,68^{\mathrm{def}}$ \\
\hline & 8 Minggu & 130,25 & $1,64 \pm 0,56^{\text {fgh }}$ & $42 \pm 15,42^{\text {cde }}$ \\
\hline & 10 Minggu & 120,50 & $1,21 \pm 0,22^{\text {abcdefg }}$ & $106 \pm 21,32^{\mathrm{h}}$ \\
\hline & 12 Minggu & 127,75 & $1,10 \pm 0,27^{\text {abcdefg }}$ & $92 \pm 12,92^{\text {gh }}$ \\
\hline SEM & & & 0.177 & 302.826 \\
\hline Probibilitas N & & & 0.000 & 0.000 \\
\hline Probibilitas M & & & 0.000 & 0.000 \\
\hline Probibilitas $N^{*} \mathrm{M}$ & & & 0.065 & 0.024 \\
\hline
\end{tabular}

Keterangan: Superskrip yang sama pada kolom yang sama menunjukkan perbedaan yang sangat nyata $(\mathrm{P}<0.01)$ 
Berdasarkan uji Duncan diketahui bahwa perlakuan $\mathrm{N}_{15} \mathrm{M}_{2}$ menghasilkan laju tumbuh tertinggi sebesar $2,5 \mathrm{~cm} /$ hari dan tidak berbeda dengan perlakuan $\mathrm{N}_{15} \mathrm{M}_{4}$ namun berbeda dengan perlakuan-perlakuan yang lain. Hasil penelitian ini menggambarkan bahwa semakin tingginya level pupuk $\mathrm{N}$ dapat mempercepat laju pertumbuhan karena $\mathrm{N}$ yang tersedia dalam tanah mencukupi kebutuhan tanaman untuk melangsungkan kehidupan. Makin banyak nitrogen yang tersedia maka proses pembelahan sel akan semakin cepat terjadi. Hal ini sesuai dengan pendapat Afifi et al. (2011) bahwa aplikasi pupuk urea pada tanaman akan meningkatkan pertumbuhan tanaman.

Tabel 1 memperlihatkan jumlah anakan tertinggi pada perlakuan $\mathrm{N}_{15} \mathrm{M}_{10}$ sebesar 106 anakan (pols) dan tidak berbeda dengan perlakuan $\mathrm{N}_{10} \mathrm{M}_{10}, \mathrm{~N}_{15} \mathrm{M}_{12}$ masingmasing sebesar 96 anakan dan 91 anakan dan berbeda dengan perlakuan-perlakuan yang lain. Hal ini menggambarkan bahwa level pupuk nitrogen dapat meningkatkan perkembangan anakan baru tanaman $S$. nitidum. Hal ini diperkirakan karena tanaman S. nitidum merupakan tanaman sifatnya anual sehingga mampu membentuk anakan yang baru sepanjang masih tersedia unsur hara dalam tanah walaupun berangsur menurun ketika memasuki fase generatif. Hasil penelitian ini sependapat dengan Tjitrosomo (1983) bahwa tumbuhan yang telah mengalami kerusakan, dapat tumbuh kembali menggantikan bagian yang telah hilang atau tetuanya dan dipertegas oleh Usman (2010) bahwa pertambahan laju tumbuh tanaman mulai dari awal penanaman secara umum berlangsung dalam tiga fase yaitu mulai dengan pertumbuhan lambat, cepat kemudian lambat lagi.

\section{Produksi Biomasa}

Hasil sidik ragam menunjukkan faktor pupuk $\mathrm{N}$ berpengaruh nyata $(\mathrm{P}<0,05)$ terhadap produksi Bahan Kering, Bahan Organik dan Serat Kasar serta memberi pengaruh yang sangat nyata $(\mathrm{P}<0,01)$ terhadap produksi Protein Kasar. Umur pemotongan berpengaruh sangat nyata $(\mathrm{P}<0,01)$ terhadap semua parameter ini namun interaksi antar faktor tidak berpengaruh $(\mathrm{P}>0,05)$ terhadap parameter-parameter tersebut seperti pada tampilan tabel 2.

Analisis statistik menunjukkan bahwa perlakuan $\mathrm{N}_{15} \mathrm{M}_{10}$ memproduksi $\mathrm{BK}$ tertinggi sebanyak 19,48 ton/ha dan berbeda dengan perlakuan-perlakuan yang lain sehingga terlihat bahwa level pemupukan memberikan peningkatan produksi BK ketika dipanen pada umur 70-84 hari. Begitu juga dengan produksi $\mathrm{BO}$, dimana perlakuan $\mathrm{N}_{15} \mathrm{M}_{10}$ mampu memproduksi BO sebesar 2,61 ton/ha yang berbeda dengan perlakuan yang lainnya. Selanjutnya protein kasar tertinggi diproduksi oleh perlakuan $\mathrm{N}_{15} \mathrm{M}_{8}$ sebesr 0,31 ton/ha yang berbeda pula dengan perlakuan yang lain. Sedangkan produksi serat kasar tertinggi kembali lagi dihasilkan oleh perlakuan $\mathrm{N}_{15} \mathrm{M}_{10}$ sebesar 1,28 ton/ha yang berbeda sangat nyata dengan perlakuan-perlakuan yang lainnya. 
Tabel 2. Produksi biomasa rumput Sorghum nitidum akibat perlakuan

\begin{tabular}{|c|c|c|c|c|c|}
\hline $\begin{array}{l}\text { Dosis } \\
\text { Pupuk }\end{array}$ & $\begin{array}{c}\text { Umur } \\
\text { Tanam } \\
\text { an }\end{array}$ & $\begin{array}{l}\text { Produksi } \\
\text { Bahan Kering } \\
\text { (t/ha) }\end{array}$ & $\begin{array}{l}\text { Produksi Bahan } \\
\text { Organik (t/ha) }\end{array}$ & $\begin{array}{l}\text { Produksi } \\
\text { Protein Kasar } \\
\text { (t/ha) }\end{array}$ & $\begin{array}{l}\text { Produksi Serat } \\
\text { Kasar (t/ha) }\end{array}$ \\
\hline \multirow{6}{*}{$\mathrm{N}_{0}$} & $\mathrm{M}_{2}$ & $0.07 \pm 0,02^{\mathrm{a}}$ & $0,01 \pm 0,00^{\mathrm{a}}$ & $0,00 \pm 0,00^{\mathrm{a}}$ & $0,00 \pm 0,00^{\mathrm{a}}$ \\
\hline & $\mathrm{M}_{4}$ & $0.26 \pm 0,12^{\mathrm{a}}$ & $0,04 \pm 0,02^{\mathrm{a}}$ & $0,01 \pm 0,01^{\mathrm{a}}$ & $0,02 \pm 0,01^{\mathrm{a}}$ \\
\hline & $\mathrm{M}_{6}$ & $0.94 \pm 0,97^{\mathrm{a}}$ & $0,13 \pm 0,13^{\mathrm{a}}$ & $0,02 \pm 0,02^{\mathrm{a}}$ & $0,05 \pm 0,05^{\mathrm{a}}$ \\
\hline & $\mathrm{M}_{8}$ & $2.19 \pm 0,56^{\mathrm{ab}}$ & $0,29 \pm 0,07^{\mathrm{a}}$ & $0,04 \pm 0,01^{\mathrm{ab}}$ & $0,12 \pm 0,03^{a b}$ \\
\hline & $\mathrm{M}_{10}$ & $6.36 \pm 5,65^{a b c}$ & $0,83 \pm 0,77^{\mathrm{ab}}$ & $0,08 \pm 0,08^{a b c}$ & $0,42 \pm 0,37^{\mathrm{abcd}}$ \\
\hline & $\mathrm{M}_{12}$ & $8.05 \pm 5,88^{\mathrm{bcd}}$ & $1,03 \pm 0,74^{\mathrm{abc}}$ & $0,10 \pm 0,07^{\mathrm{abcd}}$ & $0,53 \pm 0,39^{\text {bcde }}$ \\
\hline \multirow{6}{*}{$\mathrm{N}_{5}$} & $\mathrm{M}_{2}$ & $0.11 \pm 0,04^{\mathrm{a}}$ & $0,02 \pm 0,01^{\mathrm{a}}$ & $0,00 \pm 0,00^{\mathrm{a}}$ & $0,00 \pm 0,01^{\mathrm{a}}$ \\
\hline & $\mathrm{M}_{4}$ & $0.28 \pm 0,18^{\mathrm{a}}$ & $0,04 \pm 0,03^{\mathrm{a}}$ & $0,01 \pm 0,01^{\mathrm{a}}$ & $0,01 \pm 0,01^{\mathrm{a}}$ \\
\hline & $\mathrm{M}_{6}$ & $1.07 \pm 0,85^{\mathrm{a}}$ & $0,16 \pm 0,12^{\mathrm{a}}$ & $0,03 \pm 0,02^{a b}$ & $0,06 \pm 0,05^{\mathrm{a}}$ \\
\hline & $\mathrm{M}_{8}$ & $5.48 \pm 2,89^{\mathrm{abc}}$ & $0,80 \pm 0,42^{\mathrm{ab}}$ & $0,13 \pm 0,07^{\mathrm{bcd}}$ & $0,32 \pm 0,17^{\mathrm{abc}}$ \\
\hline & $\mathrm{M}_{10}$ & $14.00 \pm 15,15^{\mathrm{de}}$ & $2,03 \pm 2,20^{\mathrm{de}}$ & $0,20 \pm 0,22^{\mathrm{de}}$ & $0,87 \pm 0,94^{\mathrm{e}}$ \\
\hline & $\mathrm{M}_{12}$ & $10.37 \pm 6,19^{\mathrm{cd}}$ & $1,51 \pm 0,90^{\mathrm{bcd}}$ & $0,15 \pm 0,09^{\mathrm{cd}}$ & $0,64 \pm 0,39^{\text {cde }}$ \\
\hline \multirow{6}{*}{$\mathrm{N}_{10}$} & $\mathrm{M}_{2}$ & $0.12 \pm 0,03^{\mathrm{a}}$ & $0,02 \pm 0,01^{\mathrm{a}}$ & $0,00 \pm 0,00^{\mathrm{a}}$ & $0,01 \pm 0,01^{\mathrm{a}}$ \\
\hline & $\mathrm{M}_{4}$ & $0.22 \pm 0,10^{\mathrm{a}}$ & $0,03 \pm 0,01^{\mathrm{a}}$ & $0,01 \pm 0,01^{\mathrm{a}}$ & $0,01 \pm 0,01^{\mathrm{a}}$ \\
\hline & $\mathrm{M}_{6}$ & $0.77 \pm 0,58^{\mathrm{a}}$ & $0,11 \pm 0,08^{\mathrm{a}}$ & $0,02 \pm 0,01^{\mathrm{a}}$ & $0,05 \pm 0,03^{\mathrm{a}}$ \\
\hline & $\mathrm{M}_{8}$ & $3.4 \pm 3,12^{\mathrm{ab}}$ & $0,49 \pm 0,45^{\mathrm{a}}$ & $0,08 \pm 0,07^{a b c}$ & $0,21 \pm 0,20^{a b}$ \\
\hline & $\mathrm{M}_{10}$ & $13.49 \pm 6,86^{\mathrm{de}}$ & $1,93 \pm 0,98^{\text {cde }}$ & $0,20 \pm 0,11^{\mathrm{de}}$ & $0,82 \pm 0,42^{\mathrm{de}}$ \\
\hline & $\mathrm{M}_{12}$ & $10.58 \pm 5,28^{\mathrm{cd}}$ & $1,51 \pm 0,75^{\mathrm{bcd}}$ & $0,15 \pm 0,08^{\mathrm{cd}}$ & $0,64 \pm 0,32^{\text {cde }}$ \\
\hline \multirow{6}{*}{$\mathrm{N}_{15}$} & $\mathrm{M}_{2}$ & $0.18 \pm 0,09^{\mathrm{a}}$ & $0,03 \pm 0,01^{\mathrm{a}}$ & $0,01 \pm 0,01^{\mathrm{a}}$ & $0,01 \pm 0,01^{\mathrm{a}}$ \\
\hline & $\mathrm{M}_{4}$ & $0.57 \pm 1,19^{\mathrm{a}}$ & $0,08 \pm 0,03^{\mathrm{a}}$ & $0,01 \pm 0,01^{\mathrm{a}}$ & $0,03 \pm 0,01^{\mathrm{a}}$ \\
\hline & $\mathrm{M}_{6}$ & $2.57 \pm 0,54^{\mathrm{ab}}$ & $0,37 \pm 0,08^{\mathrm{a}}$ & $0,06 \pm 0,01^{\mathrm{abc}}$ & $0,13 \pm 0,03^{a b}$ \\
\hline & $\mathrm{M}_{8}$ & $6.46 \pm 3,00^{a b c}$ & $0,94 \pm 0,44^{\mathrm{ab}}$ & $0,14 \pm 0,07^{\mathrm{cd}}$ & $0,33 \pm 0,16^{\mathrm{abc}}$ \\
\hline & $\mathrm{M}_{10}$ & $19.48 \pm 5,80^{\mathrm{e}}$ & $2,81 \pm 0,83^{\mathrm{e}}$ & $0,29 \pm 0,08^{\mathrm{e}}$ & $1,28 \pm 0,39^{\mathrm{f}}$ \\
\hline & $\mathrm{M}_{12}$ & $13.53 \pm 4,36^{\mathrm{de}}$ & $0,95 \pm 0,63^{\text {cde }}$ & $0,20 \pm 0,06^{\mathrm{de}}$ & $0,89 \pm 0,29^{\mathrm{e}}$ \\
\hline \multicolumn{2}{|l|}{ SEM } & 20.484 & 0.418 & 0.005 & 0.081 \\
\hline \multicolumn{2}{|c|}{ Probibilitas N } & 0.022 & 0.011 & 0.002 & 0.024 \\
\hline \multicolumn{2}{|c|}{ Probibilitas M } & 0.000 & 0.000 & 0.000 & 0.000 \\
\hline \multicolumn{2}{|c|}{ Probibilitas } & 0.652 & 0.537 & 0.465 & 0.550 \\
\hline $\mathrm{N}^{*} \mathrm{M}$ & & & & & \\
\hline
\end{tabular}

Keterangan: Superskrip yang sama pada kolom yang sama menunjukkan perbedaan yang sangat nyata $(\mathrm{P}<0.01)$

Tabel diatas diketahui bahwa produksi bahan kering tertinggi dikarenakan umur pemotongannya lebih lama dan level pemupukan yang lebih tinggi jika dibanding dengan umur pemotongan 14-42 hari dan perlakuan kontrol. Semakin lama umur pemotongan dan meningkatnya level pupuk $\mathrm{N}$ akan 
menyebabkan akumulasi bahan kering. Hal ini sesuai dengan pendapat Sitompul dan Guritno (1995) yang menyatakan bahwa pertumbuhan adalah proses dalam kehidupan tanaman yang mengakibatkan perubahan tanaman semakin besar dan juga menentukan hasil tanaman.

Bertambahnya umur tanaman dan level pupuk diikuti dengan meningkatnya produksi bahan kering, bahan organik dan protein kasar. Subagio dan Kusmartono (1988) dikutip Mansyur et al. (2005) bahwa produksi bahan kering akan bertambah dengan bertambahnya umur pemotongan. Pada tanaman yang tua hasil aktivitas fotosintesis selain digunakan untuk pertumbuhan juga disimpan sebagai cadangan makanan sehingga kandungan dan produksi bahan kering bertambah dengan meningkatnya umur pemotongan.

Purbajanti (2013) menyatakan bahwa jumlah unsur hara terbesar yang dibutuhkan oleh tanaman adalah nitrogen serta komponen utama berbagai senyawa didalam tubuh tanaman yaitu; asam amino, amida, protein, klorofil dan alkaloid $40-45 \%$ protoplasma tersusun dari senyawa yang mengandung $\mathrm{N}$. Selanjutnya dijelaskan bahwa ketersediaan nitrogen bagi tanaman tergantung mineralisasi tergantung mikrobia yaitu mengubah $\mathrm{N}$ organik menjadi $\mathrm{NH}_{4}$ dan selanjutnya dioksidasi menjadi $\mathrm{NO}_{3}$ yang dibutuhkan tanaman

Peningkatan produksi bahan organik dan protein kasar pada penelitian ini mengikuti peningkatan produksi bahan kering, jadi meskipun kandungan protein kasar menurun akan tetapi karena kandungan bahan kering meningkat dengan bertambahnya umur dan level pupuk N, maka produksi protein kasar masih tetap meningkat. Hal ini didukung oleh pendapat Koten (2013) bahwa makin banyaknya dosis pupuk urea maka semakin banyak pula nitrogen yang tersedia yang akan memaksimalkan proses fotosintesis dan meningkatkan akumulasi hasil fotosintesis pada bagian tanaman. Fotosintesis dipengaruhi oleh daya kerja peralatan fotosintesis diantaranya adalah klorofil karena klorofil mengandung nitrogen. Selanjutnya dijelaskan bahwa semakin banyak klorofil yang tersedia maka makin tinggi pula hasil fotosintesis. Hal ini sesuai pendapat AAK (1985) bahwa semakin tua tanaman akan semakin banyak serabut yang digenangi oleh lignin yang mengeraskannya sehingga kebanyakan dari sel-sel tanaman itu diselubungi oleh zat yang tak dapat dicernakan dan itulah yang mnyebabkan menurunnya nilai gizi tanaman.

\section{KESIMPULAN}

Rumput Sorghum nitidum merupakan pakan lokal Nusa Tenggara Timur yang sudah beradaptasi dengan kondisi kekeringan. Kenyataan lapangan terlihat bahwa tanaman ini mampu tumbuh diberbagai tempat namun jika menghasilkan hijauan pakan berkuaitas baik dan berproduksi tinggi maka tanaman ini dipanen tepat waktu dan diberi perlakuan pupuk $\mathrm{N}$ untuk memacu 
pertumbuhannya. Penelitian membuktikan bahwa pada perlakuan pupuk sebanyak 150 $\mathrm{kg} / \mathrm{ha}$ pada umur 56 hari, memberi peningkatan pada produksi dan kualitas hijauan. Hal ini terjadi karena kondisi NTT yang kering dapat menyebabkan cepatnya penuaan tanaman sehingga dapat menurunnya kualitas dan produksi hijauan. Penambahan pupuk $\mathrm{N}$ dapat memacu kerja enzim dalam beraktifitas sehingga dapat menghasilkan tanaman pakan berkualitas baik dan berproduksi tinggi.

\section{DAFTAR PUSTAKA}

Ari T, Purwanto, Budiyono. 2013. Efisiensi Penggunaan Pupuk N Untuk Pengurangan kehilangan Nitrat pada Lahan Kering. Proseding Seminar Nasional pengelolaan Sumber Daya Alam dan Lingkungan.

Gomez, K. A., dan A. A. Gomez. 1995. Prosedur Statistika Untuk Penelitian pertanian. Edisi Kedua. Penterjemah : E. Sjamsudin dan J. S Baharsjah. Penerbit UI Press, Jakarta.

Kamlasi, Y. 2014. Pola Produksi dan Nutrisi Rumput Kume (Sorghum plumosum var. timorese) Pada Lingkungan Alamiahnya Disertai Manajemen Pemotongan. Tesis. Program Pasca Sarjana Program Studi Ilmu Peternakan Universitas Nusa Cendana. Kupang.

Keraf, F.K., Y. Nulik dan M.L. Mullik. 2015. Pengaruh Pemupukan
Nitrogen dan Umur Tanaman terhadap Produksi dan Kualitas Rumput Kume (Sorghum plumosum var. timorense). Jurnak Peternakan Indonesia. 17 (2): 123130

Keraf, F. K. 2016. Pengaruh Pemupukan Nitrogen terhadap pertumbuhan dan produksi Rumput Kume (Sorghum plumosum var. timorense). Prosiding. Fakultas Pertanian Universitas Nusa Cendana Kupang: 39-49

Koten, B. 2013. Tumpangsari Legum Arbila (Phaseolus lunatus L) Berinokulum Rizobium dengan Sorgum (Sorghum bicolor (L) Moench) dalam Upaya Meningkatkan Produktivitas Hijauan Pakan Ruminansia. Desertasi. Program Pasca Sarjana Program Fakultas Peternakan Universitas Gajah Madah. Yogyakarta.

Koten, B. 2012. Produksi Tanaman Sorgum (Sorghum bicolor (L) Moench) Varietas Lokal Rote Sebagai Hijauan Pakan ternak Ruminansia pada Umur Panen dan dan Dosis Pupuk Urea yang Berbeda. Buletin Peternakan. 36 (3): 150-155.

Madarisa, F., I. Iskandar, dan D. Andalina. 2007. Analisa Potensi Bahan Pakan Lokal untuk Pengembangan Ternak Sapi Potong di Sumatera Barat. Jurnal 
Peternakan Indonesia. 12 (3):182194.

Mansyur et al. 2006. Pengaruh Interval Pemotongan Rumput Brachiaria humidicola (Rendle) Scweick Terhadap Konsentrasi Amonia dan Asam Lemak Terbang (in vitro). Jurnal Peternakan Indonesia. 11 (1): 50-56.

Purbajanti, E.D. 2013. Rumput dan Legum Sebagai Hijauan Makanan Ternak. Graha Ilmu. Yogyakarta

Purbajanti. S. Anwar. S. Widyati dan F. Kusmiyati. Kandungan protein dan Serat kasar Rumput Benggala (Panicum maximum) dan Rumput Gajah (Pennisetum pupureum) Pada Cekaman Stres Kering. Makalah Animal Production. 11 (2) 109-115.

Sawen, D. 2012. Pertumbuhan Rumput Gajah (Pennisetum purpureum) dan Benggala (Panicum maximum) Akibat Perbedaan Intensitas Cahaya. Jurnal Ilmu Ternak dan Tanaman. 2 (1) : 1720
Seseray, D.Y., B. Santoso dan M. N. Lekito. 2013. Produksi Rumput Gajah (Pennisetum purpureum) yang Diberi Pupuk N, P dan K dengan Dosis 0, 50 dan 100\% pada Devoliasi Hari ke-45. Jurnal Sains Peternakan. 11 (1) : 49-55.

Sowmen, S., L. Abdullah, P. D. M. H. Karti and D. Soepandi. 2014. Adaptasi Legum Pohon yang Diinokulasi dengan Fungi Mikoriza Arbuskular (FMA) Saat Cekaman Kekeringan. Jurnal Peternakan Indonesia (Indonesian Journal of Animal Science). 16 (1): $46-54$.

Steel, R. G. D., dan J. H. Torrie. 1993. Prinsip dan Prosedur Statistika: Suatu Pendekatan Biometrik. Edisi kedua. Ahli Bahasa: B. Sumatri. PT. Gramedia Pustaka Utama, Jakarta.

Yoku, O., D.Soetrisno, R. Utomo dan S.A. Siradz. 2007. Pengaruh Perlakuan Jarak Tanam dan Pemupukan NPK terhadap Produksi Rumput Sudan (Sorghum sudanese). Jurnal Agritek. 15: 81-87. 